\title{
Deforestation and the Sumatera elephant roaming area in East Aceh Regency
}

\author{
Lady Hafidaty Rahma Kautsar ${ }^{1, *}$, Amrih Halil $^{1}$ \\ ${ }^{1}$ Magister of Geography, University of Indonesia, UI Depok Campus, Depok, 16424, Indonesia,
}

\begin{abstract}
Reduced forest or deforestation is widespread in East Aceh Regency for plantation, agriculture and settlement purposes. Forests in Sumatra, including in East Aceh Regency are Sumatran Elephant habitat (Elephas maximus sumatranus). However, encroachment resulted in this fauna threatened sustainability, whereas Sumatran elephants are endangered species protected by law both since Dutch colonialism, post-independence, and international regulations, and Sumatran elephants have an vital ecosystem role but are seen as a nuisance to the local economy in East Aceh Regency, so it is not electrocuted, killed and abused. This paper reviews the deforestation of the Sumatran Elephant in East Aceh Regency. The results of the study show that elephant roaming areas intersect with deforestation that occurred in East Aceh Regency. As an alternative local economy, there is still the potential of ecotourism with the mascot of the Sumatran elephant. Thus the Sumatran elephant is still able to be sustainable, and the forest as habitat is maintained.
\end{abstract}

\section{Introduction}

Sumatra is facing the fastest rate of forest deforestation or deforestation in Southeast Asia, reaching even 3,2$5,9 \%$ [1]. During the 2000-2009 the most massive deforestation rate after Kalimantan was Sumatra with a percentage of $24.49 \%$ [2]. The causes of the loss of Sumatra's forests are illegal and non-illegal logging, plantation development, especially oil palm and wood for paper, conversion of agricultural land by migrants through the Indonesian government's transmigration program, and forest fires [3].

East Aceh Regency is the largest regency of 23 districts/cities in Nanggroe Aceh Darussalam (NAD), in Sumatra $(6,040.60 \mathrm{~km} 2$ or $10.53 \%$ of the total area of NAD Province). Located at $409^{\prime} 21,08^{\prime \prime}$ - $5^{\circ} 06^{\prime} 02,16^{\prime \prime}$ North latitude and $97^{\circ} 15^{\prime} 22,07^{\prime \prime}$ - 9734'47,22" east longitude, this regency is quite strategic because it is on the east coast of NAD Province and passed by the main road Medan-Banda Aceh, so it has the considerable economic potential[4]. In addition, this district is also the destination of transmigration.

Agriculture is a base sector in East Aceh Regency. The most significant contributors to GRDP each year are agriculture, forestry, and fishery (up from $37.12 \%$ in 2012 to $45.97 \%$ in 2016). The Mining and Quarrying Sector ceased to be the second largest contributor of GDP since 2014. In the last five years, however, the GDP growth rate of the Agriculture, Forestry and Fishery Sectors has been very fluctuating and is slowing down in 2016 to $2.31 \%$, or slower of all other business fields, except for the Mining and Quarrying Sector ($44.45 \%)$. [5]
The development of transmigration and settlement areas, as well as plantations in the south of East Aceh Regency, resulted in the encroachment of forest which is the habitat of wildlife, including the Sumatran Elephant (Elephas maximus sumatranus). Sumatran elephants include animals that have an extensive range of roaming areas. Elephant roaming range is quite varied depending on the availability of feed and water. If the availability of feed and water is sufficient, and the disruption is small, it is possible for a small range [6].

The presence of elephants in areas where human activity occurs, after deforestation for the economy, causes conflict between elephants and humans. The increase of Sumatran elephant death due to HEC (human-elephant conflict) factor is quite sharp from 8 cases to 45 cases [7].

Therefore, it becomes a further urgency to search for deforestation with elephant roaming areas. Given, the elephant is a protected animal since the Dutch colonial, the Wildlife Protection Act of 1931 Number 134 and 266 [8], post-independence Indonesia (Decree of the Minister of Agriculture No.234 / Kpts / Um / 1972 and Government Regulation of the Republic of Indonesia No. 7 of 1999 on the Preservation of Plant Species), and international regulations, namely CITIES (Convention on International Trade in Endangered Species of Wild Flora and Fauna) which classify elephants in the list of Appendix I which are wild animals that should not be traded internationally, either ivory or other body parts [9].

Corresponding author: lady.hafidaty@gmail.com 


\section{The material and method}

The data used are:

- Landcover forest maps processed from Landsat imagery from 2006 to 2016, i.e. in 2006, 2009, 2014, 2015. [10]

- Land use map 2015 [11]

- Map of the Sumatera Elephant Explore Area [12]

The data are analyzed by the overlay method using ArcGIS 10.1 software. The area of deforestation with the elephant roaming area became the forerunner to the potential location of human-elephant conflict. In addition to the land use map, what land use will be and where potential conflicts occur.

\section{Results and discussion}

The highest defenses of deforestation in East Aceh district in 2006-2009 are in Peunaron Subdistrict (3071.80 hectares). In 2009-2014, the highest deforestation was still in Peunaron Subdistrict (4424.76 hectares). In 2014-2015, the highest deforestation in Serbajadi District (1398.49 hectares). The following year was still highest in Serbajadi Subdistrict, with an increase in the area of deforestation (1597.76 hectares). Positionally, forest clearing from central East Aceh District (Peunaron Subdistrict), further leads south (Serbajadi District). This means that the degradation of forest deforces is increasingly massive (Fig. 1. and fig.2. ).

Deforestation of East Aceh Regency in 2006-2016

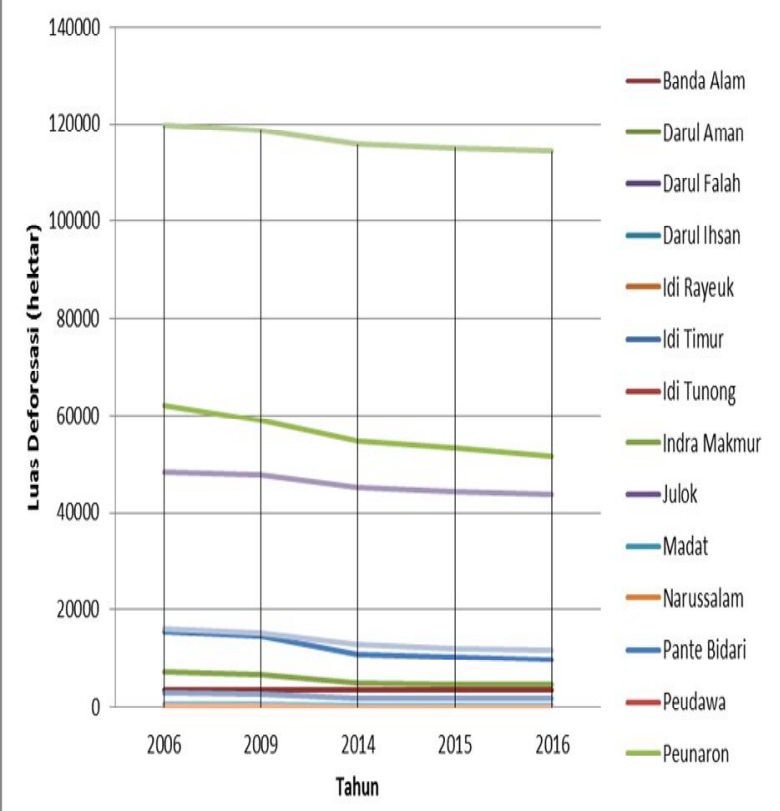

Fig. 1. Deforestation in East Aceh Regency (2006-2016)
Forest in 2016 and Deforestation from 2006-2016 in East Aceh Regency

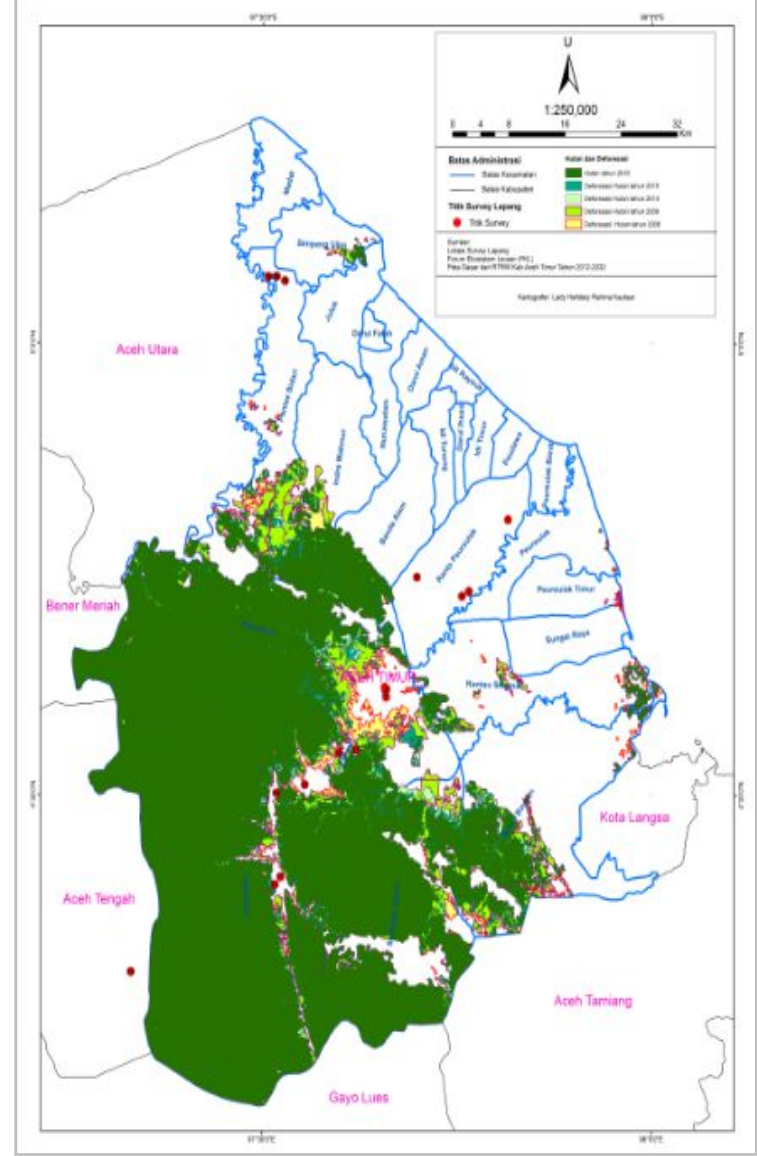

Fig. 2. Forest and Deforestation in East Aceh Regency (20062016)

The area of elephant migration in East Aceh district has a total area of $193,181.11$ hectares $(35.60 \%$ of total East Aceh district). Consecutively from the total area of high to low area of elephant roaming/migration, are:

(1) Peunaron Subdistrict (60100.88 Hectares or $79.94 \%$ of East Aceh District)

(2) District Simpang Jernih (42824.66 Hectares or $74.43 \%$ of East Aceh Regency)

(3) Pante Bidari Subdistrict (19587,76 Hectares or $53,41 \%$ from East Aceh Regency)

(4) District of Serba Jadi $(47,411.16$ hectares or $37.96 \%$ of East Aceh Regency)

(5) Indra Makmur sub-district (7,194.82 hectares or $29.35 \%$ of East Aceh district)

(6) Banda Alam sub-district $(3,818.24$ hectares or $21.17 \%$ of East Aceh district)

(7) Kecamatan Birem Bayeun (9552.33 hectares or $18.75 \%$ of East Aceh district)

(8) Ranto Peureulak Subdistrict (2425.61 hectares or $10.80 \%$ of East Aceh Regency)

(9) Rantau Selamat District (265.65 hectares or $0.96 \%$ of East Aceh district). 


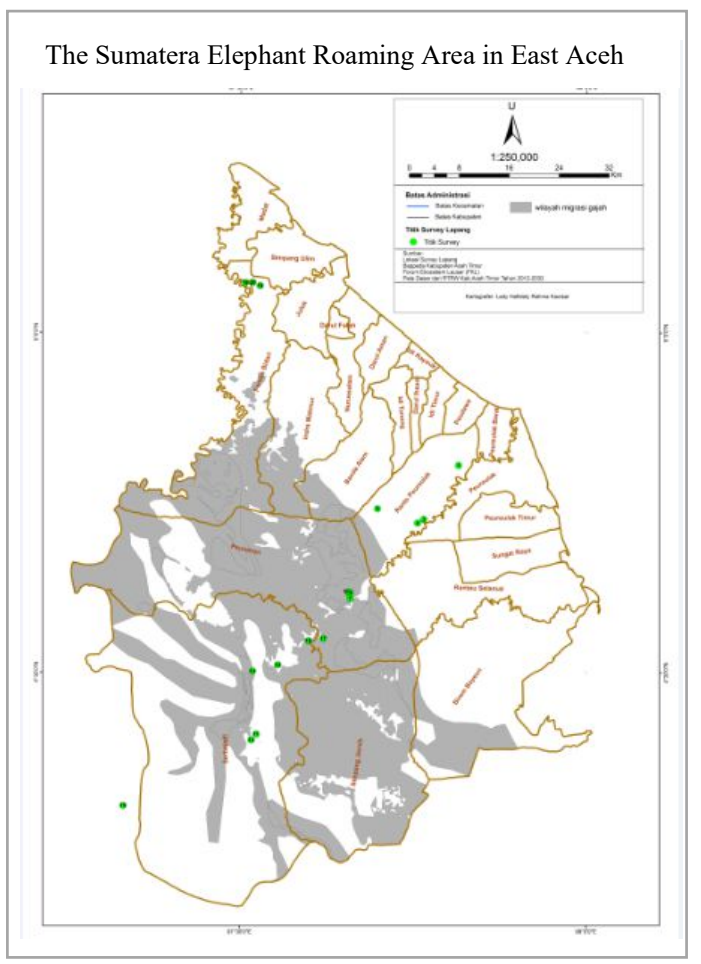

Fig. 3. The Sumatera Elephant Roaming Area in East Aceh Regency

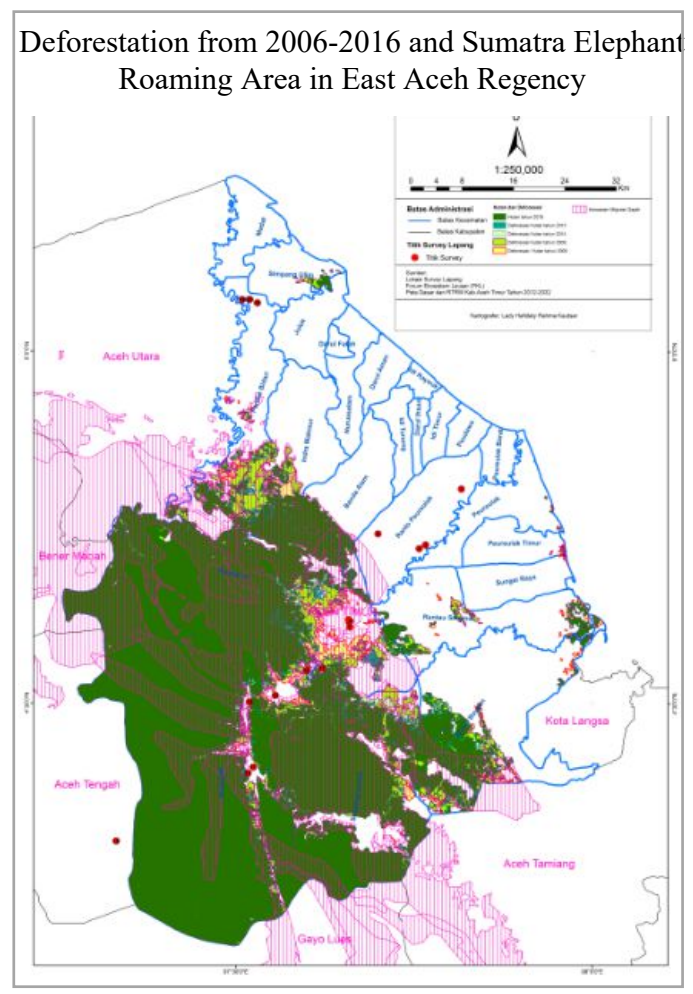

Fig. 4. Deforestation in 2006-2016 and the Sumatera Elephant Roaming Area in East Aceh Regency

Based on the above map (Fig. 4. and 3.), the elephant roaming area covered almost half of the district of East Aceh, precisely $35.60 \%$ entire East Aceh district or an area of 193,181.11 hectares. Deforestation in the elephant roaming area in East Aceh Regency is closely related to the population of East Aceh people, mainly due to transmigration.

The government in East Aceh Regency since 2013, declared the development of Integrated Regions of Independent (KTM) Seumanah Jaya themed "Development of Integrated Regional Integrated City Transmigration (KTM) Seumanah Jaya, can Forge One Unity Development System and Economic Growth of Growing Area in Regency East Aceh ". The sub-districts in the development include Peunaron Sub-district, Ranto Peureulak Sub-District, and Serbajadi Sub-district. The fundamental law of development is contained in:

1. Decree of the Minister of Manpower and Transmigration of the Republic of Indonesia Number: B.243 / MEN / P2KT-PTPKT / XII / 2013, December 31st, 2013, Subject: License of Principles of Development and Integrated Urban Development (KTM) Seumanah Jaya East Aceh Regency.

2. Qanun East Aceh Regency Number: 10 the Year 2015, Date December 16, 2015, About: Integrated Seamate Jaya Independent City Area (Table 1).

Table 1. Integrated Urban Development (KTM) Seumanah Jaya, East Aceh Regency

\begin{tabular}{|c|c|c|c|c|}
\hline \multirow[t]{2}{*}{ No } & \multirow[t]{2}{*}{$\begin{array}{c}\text { Sub- } \\
\text { District }\end{array}$} & \multirow{2}{*}{$\begin{array}{l}\text { Gampong } \\
\text { (Village) }\end{array}$} & \multicolumn{2}{|c|}{$\begin{array}{l}\text { Spatial Pattern based on } \\
\text { RTRW of.East Aceh } \\
\text { Regency in 2012-2032 }\end{array}$} \\
\hline & & & $\begin{array}{l}\text { Protected } \\
\text { Area }\end{array}$ & $\begin{array}{c}\text { Cultivation } \\
\text { Area }\end{array}$ \\
\hline 1 & $\begin{array}{l}\text { Peunar } \\
\text { on }\end{array}$ & $\begin{array}{l}\text { 1). Gampong } \\
\text { Arul Pinang } \\
\text { 2). Gampong } \\
\text { Bukit Tiga } \\
\text { 3). Gampong } \\
\text { Sri Mulya } \\
\text { 4). Gampong } \\
\text { Peunaron } \\
\text { Baru } \\
\text { 5). Gampong } \\
\text { Peunaron } \\
\text { Lama }\end{array}$ & $\begin{array}{l}\text {-River } \\
\text {-River } \\
\text { Boundary } \\
\text {-Protected } \\
\text { Forest } \\
\text {-Production } \\
\text { Forest }\end{array}$ & $\begin{array}{l}\text {-Rural } \\
\text { Settlements } \\
\text {-Urban } \\
\text { Settlements } \\
\text {-Agriculture } \\
\text { Wetlands } \\
\text {-Large } \\
\text { plantations } \\
\text { - } \\
\text { Transmigratio } \\
\mathrm{n} \\
\text {-Community- } \\
\text { owned } \\
\text { plantation }\end{array}$ \\
\hline 2 & $\begin{array}{l}\text { Ranto } \\
\text { Peureul } \\
\text { ak }\end{array}$ & $\begin{array}{l}\text { 1). Gampong } \\
\text { Seumanah } \\
\text { Jaya; } \\
\text { 2). Gampong } \\
\text { Punti Payong; } \\
\text { 3). Gampong } \\
\text { Alue Genteng; } \\
\text { 4). Gampong } \\
\text { Beurandang }\end{array}$ & $\begin{array}{l}\text {-River } \\
\text {-River } \\
\text { Boundary } \\
\text {-Production } \\
\text { Forest }\end{array}$ & $\begin{array}{l}\text {-Rural } \\
\text { Settlements } \\
\text {-Agriculture } \\
\text { Wetlands } \\
\text {-Dryland } \\
\text { Farming } \\
\text { Large } \\
\text {-Plantations } \\
\text {-Mining } \\
\text {-Middle } \\
\text { Industry } \\
\text {-Community- } \\
\text { owned } \\
\text { plantation }\end{array}$ \\
\hline 3 & $\begin{array}{l}\text { Serba } \\
\text { Jadi }\end{array}$ & $\begin{array}{l}\text { 1). Gampong } \\
\text { Arul Durin; } \\
\text { 2). Gampong } \\
\text { Bunin; dan } \\
\text { 3). Gampong } \\
\text { UPT - I Kuala } \\
\text { Pango. }\end{array}$ & $\begin{array}{l}\text {-River } \\
\text {-River } \\
\text { Boundary } \\
\text {-Protected } \\
\text { Forest } \\
\text {-Production } \\
\text { Forest }\end{array}$ & $\begin{array}{l}\text {-Rural } \\
\text { Settlements } \\
\text {-Wet } \\
\text { Agriculture } \\
\text {-Large } \\
\text { Plantations } \\
\text {-Mining } \\
\text { - } \\
\text { Transmigratio } \\
\text { n } \\
\text {-Community- } \\
\text { owned } \\
\text { plantation }\end{array}$ \\
\hline
\end{tabular}


In contrast, in three sub-districts proclaimed for this transmigration area, some are included in the elephant roaming area, so the potential for human-elephant conflict is vulnerable to recurrence. Elephant roaming area in each sub-district is Peunaron Sub-district 79.94\% (60100.88 Hectares), Ranto Peureulak Sub-district $10.80 \%$ (2425.61 hectares), and Sub-district of Serba Jadi $37.96 \% \quad(47,411.16$ hectares) (Table $1 . \quad$ ). Deforestation in the elephant roaming area results in loss of habitat, elephant feed, and water source for elephant life. As a result, elephants are increasingly looking for suitable locations for their habitats, and elephants penetrate into the locations of the population, as well as the cultivated commodities, which elephants favor. Therefore, there is a need for a strategy to prevent the recurrence of elephant-human conflict, after the deforestation for the economic activities of the community.

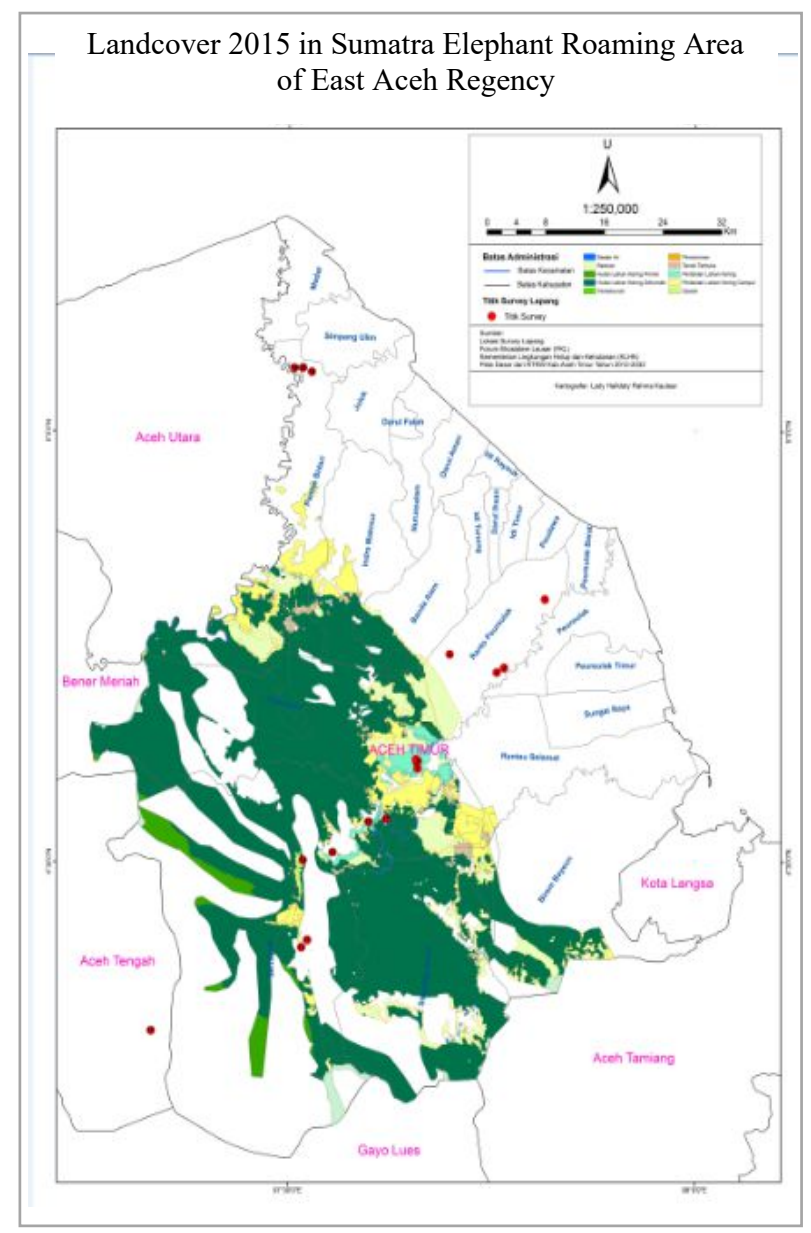

Fig. 5. Landuse in 2015 and the Sumatera Elephant Explore in East Aceh Regency

Land cover on elephant migration areas in Aceh Timur Regency (Fig. 5.), consisting of water bodies, shrubs, secondary dryland forests, dryland farming, mixed dryland farming, open land, plantations, and paddy fields. Meanwhile, conflict-prone areas of elephant migration are located in forest areas which are then encroached into areas of human activities, such as paddy fields, plantations, dryland farming, mixed-field farming. Even settlements, given the term settlements, also did not escape the area of migration of elephants.

Several commodities in the area that are in contact with elephant migration are non-intensified paddy, intensified paddy, upland paddy, soybeans, corn, rubber, palm oil, areca nut, and cocoa. Prone to conflict occurs because elephants have their roaming cycles for feeding. Elephants are not only in forest areas but up to $20 \mathrm{~km}$ from the forest area, massive and very high social impact [13]. If you grow food that elephants favor, then the elephant will cross it. In the past, elephants did not cross citrus commodities, and other commodities because they were not food. But now, the commodities grown are elephant food, such as oil palm, so to prevent social conflict between humans and elephants, it is necessary to take preventive measures.

Preventive actions that can be done so that no more extended human-elephant conflict is replacing the elephant preferred commodity into a commodity that elephants do not like. In addition, deforestation should no longer be done, because it will intersect with the elephant roaming area, causing a new conflict. Therefore, the optimization of substitute commodity becomes essential. If substitution is impossible, a "commodity fence" that elephants do not like. The fence of this commodity becomes a barrier between the elephant roaming area and the economic commodity area that elephants favor, but empowered the community. However, further study is needed on how much distance is required regarding this "commodity fence."

Economic activity that can be an alternative is ecotourism with an elephant mascot in East Aceh Regency. Sumatran elephant is a rare animal that can be the attraction of foreign and domestic tourists. In addition, the use of forest values without deforestation, for example, is to empower forest honey, as well as medicines from the forest.

\section{Conclusion}

Deforestation in East Aceh Regency is caused by settlement, especially transmigration, oil palm plantation, and land empowerment for commodities such as paddy (non-intensification and intensification), upland paddy, soybeans, corn, rubber, palm oil, areca nut, and cocoa. The Sumatra Elephant roaming area is disturbed by deforestation. This is because there are areas of elephant roaming that intersect with deforestation location in East Aceh Regency. Even elephants, according to their instincts, search for habitats that contain feed and water resources, to the territory of the population. As a result, there is a human-elephant conflict. There is a need for conflict prevention strategies since elephants are protected wildlife, as well as useful for maintaining ecosystems, such as seed propagation and flora growth control. This strategy can be in the form of developing ecotourism with Sumatran elephants as a mascot. Optimizing forests as an economic commodity through harvesting forest products in the form of forest honey, as well as medicines can be another alternative. 
We would like to thank Causal Productions for Department of the Geography University of Indonesia and Forum Ekosistem Leuser.

\section{References}

1. Achard F, Eva H D, Stibig HJ, Mayaux P, Gallego J, Richards $\mathrm{T}$ And Malingreau J P. Determination of Deforestation Rates of The World's Humid Tropical Forests. Science 297 999-1002. 2002.

2. Wirendro Sumargo et.al. Portrait of Indonesia's Forest Condition for the Period of 2000-2009. Bogor: Forest Watch Indonesia (FWI). 2011.

3. Kinnaird, MF, EW. Sanderson, TG. O'Brien, HT.Wibisono \& G. Woolmer. Deforestation Trendsin a Tropical Landscape and Implications for Endangered Large Mammals. Cons. Biol., 17:245257. 2003.

4. BPS East Aceh Regency. East Aceh in Figures 2017. BPS East Aceh Regency Timur, Idi. 2017.

5. BPS East Aceh Regency. Gross Regional Domestic Product by Business Field East Aceh District 20122016. BPS Kabupaten Aceh Timur, Idi. 2016

6. Whyte, I.J. Studying Elephant Movements. African Wildlife Foundation. Nairobi. Kenya. 1996.

7. Sukmantoro W., Syamsuardi., Sudibyo.,dan Adan Suprahman. H. Canal Design or Elephant Trench as part of Elephant-Human conflict mitigation techniques in Tesso Nilo, Riau Province. 15 Juni 2011.

8. Jajak, M.D. Protected Animals. Jakarta. Progres. 2004.

9. (2018). Checklist of CITIES Species. [Online]. Available: http://checklist.cites.org

10. (2018) The U.S. Geological Survey. [Online]. Available: http://www.usgs.gov/

11. Kementerian Lingkungan Hidup dan Kehutanan. Land Use Map. 2015.

12. Forum Ekosistem Leuser. 2018. Map of the Sumatera Elephant Roaming Area.

13. Rudy. 2018. Forum Ekosostem Leuser (FKL) Interview 